\title{
AN OVERVIEW OF ENTRIES LISTING FREQUENTLY RECOMMENDED WORKS AND SIMILAR GUIDES [R]
}

B-39 Other United States and Canadian Libraries of Importance for Students of English and American Language and Literature

B-59 Other British Libraries of Importance to Students of English and American Language and Literature

D-98 Other Major Union Lists of Periodicals

E-102 Some Current Guides to Spoken Recordings

F-56 Goldentree Bibliographies in American History

F-60 Some Standard Reference Histories of the United States

H-11 An Overview of Published Catalogs and Indexes of British Library Manuscript Collections

H-14 Some Other Catalogs of Important Manuscript Collections in British and Irish Repositories

H-27 Some Other Guides and Catalogs of Important Manuscript Collections in American Repositories

H-80 Some Guides for Research in American Archives

H-115 Some Other References of Use to Students of British Paleography

H-125 Some Other References of Use to Students of American Paleography

I-16 Some Frequently Recommended Works in Linguistics

I-17 Some Frequently Recommended Works on the History, Character, and Teaching of the English Language

I-107 Some Frequently Recommended Works on Translation Theory and Practice

I-161 Guides to Translations of Asian and African Literatures

K-24 Some Frequently Recommended Works in Folklore

K-34 Some Frequently Recommended Works on Mythology

K-44 Some Frequently Recommended Works on the History of the English Bible and on the Bible in Literary History

K-69 Some Frequently Recommended Works on Proverbs, Sententiae, and Quotations

K-79 Some Frequently Recommended Works on Symbols, Iconography, and Literary Symbolism

K-89 Some Frequently Recommended Works on Stoff- und Motivgeschichte
K-90 Some Frequently Recommended Studies in Social and Cultural History, English and American

K-91 Some Frequently Recommended Works on Costume and Courtesy-General, English, and American

K-92 Some Frequently Recommended Works on the History of Taste and Related Problems, English and American

K-95 Some Frequently Recommended Studies in Intellectual History and the History of Ideas

K-98 Some Frequently Recommended Studies in the History of Learning, Including Education, Scholarship, and Librarianship

L-4 General Guides to the Study of Comparative Literature

L-10 Some Frequently Recommended Works on Comparative, General, and World Literature

L-15 Guide to the Study of Individual Literary Terms

L-49 Some Frequently Recommended Works in Classical Studies

L-59 Some Frequently Recommended Works on Modern European Languages and Literatures

L-64 Some Frequently Recommended Works on the Romance Languages and Literatures

L-79 Some Frequently Recommended Works on French Language and Literature

L-89 Some Frequently Recommended Works on Italian Studies

L-94 Some Frequently Recommended Works on Spanish (and Portuguese) Languages and Literatures

L-101 Some Frequently Recommended Works on LatinAmerican Languages and Literatures

L-109 Some Frequently Recommended Works on the Germanic Languages and Literatures

L-120 Some Frequently Recommended Works on German Language and Literatures

L-129 Some Frequently Recommended Works on Russian, Other Slavic, and Other Eastern European Languages and Literatures

L-139 Some Frequently Recommended Works in African Studies

L-149 Some Frequently Recommended Works in Asian (Oriental) Studies 
L-153 Some Frequently Recommended Works in Near Eastem Studies

L-159 Some Frequently Recommended Works in Indian (Classical and Modem), Sinhalese, and Pakistani Studies

L-169 Some Frequently Recommended Works in Far Eastem Studies

L-180 Some Frequently Recommended Works on Children's Literature

L-190 Some Frequently Recommended Works in Women's Studies

L-199 Some Frequently Recommended Works on Women and Literature

M-8 Some Additional Guides to Reference Works for Students of English Literature

M-38 Some Other Histories of English Literature

M-60 Guide to Major-Author Reference Works

M-79 Some Frequently Recommended Works on Scottish Literature and Scottish Studies

M-94 Some Frequently Recommended Works on AngloIrish Literature, Irish Studies, and Celtic Studies

M-99 Some Frequently Recommended Works on AngloWelsh Literature and Welsh Studies

M-109 Some Frequenthy Recommended Works on Commonwealth Literature and on World Literature Written in English

M-119 Some Frequently Recommended Works on African Literature Written in English and Related African Studies

M-129 Some Frequently Recommended Works on Australian Literature

M-149 Some Frequently Recommended Works on Canadian Literature in English

M-159 Some Frequently Recommended Works on AngloIndian and Indo-English Literature

M-169 Some Frequently Recommended Works on New Zealand Literature and the Other English Literatures of the South Pacific (Excluding Australia)

M-179 Some Frequently Recommended Works on West Indian Literature in English

N-19 Some Frequently Recommended Works in Medieval Studies

N-29 Some Frequently Recommended Works in AngloSaxon Studies

N-49 Some Froquently Recommended Works in Middle English Studies

N-79 Some Frequently Recommended Works in Medieval Latin Studies

0-19 Some Frequently Recommended Works in Renaissance Studies

0-59 Some Frequently Recommended Bibliographies, Editions, Handbooks, Guides, and Other Reference Works in Shakespeare Studies

O-79 Some Frequently Recommended Works on Neo-Latin Literature

P-19 Some Frequently Recommended Works in Restoration and Eighteenth-Century Studies

Q-19 Some Frequently Recommended Works in Nineteenth-Century Studies

Q-29 Some Frequently Recommended Works on Romanticism

Q-49 Some Frequently Recommended Works in Victorian Studies
R-19 Some Frequently Recommended Works on Modern Literature

S-19 Some Frequently Recommended Works on American Literature and American Studies

S-38 Some Other Histories of American Literature

S-50 Guide to Major-Author Reference Works

S-119 Some Frequently Recommended Works on Local and Regional American Literature

S-139 Some Frequently Recommended Works on AfroAmerican Literature

S-149 Some Frequently Recommended Works on Native American Literature

S-159 Some Frequently Recommended Works on American-Jewish Literature

S-169 Some Frequently Recommended Works on Chicano Literature

S-179 Some Frequently Recommended Works on AsianAmerican Literature

T-49 Some Frequently Recommended Histories of Poetry over One or Several Periods of English or American Literary History

T-58 Some Frequently Recommended Works on the Language of Poetry

T-59 Some Frequently Recommended Works on the Reading of Poetry

T-69 Some Frequently Recommended Works on Prosody

T-89 Some Frequently Recommended Histories and Studies of One or Several of the Poetic Kinds in England or America

U-19 Some Frequently Recommended General Works on the Performing Arts, the Theater, and the Drama

U-29 Some Frequently Recommended Works on Theater Biography

U-67 Some Frequently Recommended Works on the Language and Elements of Drama

U-68 Some Frequently Recommended Works on Reading Drama

U-69 Some Frequently Recommended Works on Particular Dramatic Genres

U-80 Some Frequently Recommended Works on the History of Drama and Theater over One or Several Periods of English or American Literary History

U-98 Some Frequently Recommended Works on Literature and Film

U-99 Some Frequently Recommended Works on Film History, Theory, and Criticism

W-9 Some Frequently Recommended Works on Narratology, the History of Narrative, and the Theory of the Novel

W-27 Some Frequently Recommended Works on the Linguistic Analysis of Fictional Discourse

W-28 Some Frequently Recommended Works on Reading Fiction

W-29 Some Guides to Novels on Special Subjects or in Special Forms

W-49 Some Frequently Recommended Works on the History of Narrative Fiction, Primarily over One or Several Periods of English or American Literary History

W-59 Some Frequently Recommended Works on Short Fiction

W-69 Some Frequently Recommended Works on the Picaresque 
W-79 Some Frequently Recommended Works on Gothic Fiction

W-89 Some Frequently Recommended Works on the Historical Novel

W-99 Some Frequently Recommended Works on Detective Fiction

W-119 Some Frequently Recommended Works on Fantasy, Utopian Fiction, and Science Fiction

W-120 Some Frequently Recommended Works on the Relation between Fiction and Nonfictional Prose

W-127 Some Frequently Recommended Works on Prose Stylistics, Including the Study of Prose Rhythm

W-128 Some Frequently Recommended Works on Reading English Prose

W-129 Some Frequently Recommended Works on the History of English Prose over One or Several Periods of English or American Literary History

W-130 Some Frequently Recommended Works on the English and American Sermon

W-132 Some Frequently Recommended Works on the Character in English

W-134 Some Frequently Recommended Works on the English and American Essay

W-139 Some Frequently Recommended Works on English and American Travel Literature

W-149 Some Frequently Recommended Works on the History and Theory of Biography, Including Autobiography, Diaries, Journals, and Letters

W-157 Some Frequently Recommended Works on English and American Humor

W-158 Some Frequently Recommended Works on Irony

W-159 Some Frequently Recommended Works on the History and Theory of Satire

X-10 Guide to Historical Collections of Critical Essays

X-11 Some Frequently Recommended Works on Literary Criticism or Literary Theory before the Twentieth Century

X-14 Some Frequently Recommended Works on Modern Literature and Literary Theory before ca. 1950

X-15 Some Frequently Recommended Works on Contemporary Theory

X-19 Some Frequently Recommended Works on Czech and French Structuralism and Semiotics

X-24 Some Frequently Recommended Works on Phenomenology, Hermeneutics, Reception Theory, and Reader-Response Criticism

X-28 Some Frequently Recommended Works on Deconstruction and Poststructuralism

X-29 Guide to Collections of Excerpts from Modern Criticism

X-39 Some Frequently Recommended Works on Literature and the Other Arts and Sciences in General

X-44 Some Frequently Recommended Works on Literature and Music

X-49 Some Frequently Recommended Works on Literature and Visual Arts

X-54 Some Frequently Recommended Works on Literature and Religion

X-59 Some Frequently Recommended Works on Literature and Philosophy

X-64 Some Frequently Recommended Works on Literature and Psychology

X-69 Some Frequently Recommended Works on Literature and Sociology

X-74 Some Frequently Recommended Works on Marxist Approaches to Literature
X-78 Some Frequently Recommended Works on Literature and Politics

X-79 Some Frequently Recommended Works on Literature and Law

X-84 Some Frequently Recommended Works on Literature and History

X-89 Some Frequently Recommended Works on Literature and Science

X-94 Some Frequently Recommended Works on Literature and Medicine

X-99 Some Frequently Recommended Works on Literature and Technology

X-119 Some Frequently Recommended Works on the History of Rhetoric and Rhetorical Theory and on Relations of Rhetoric and Poetics

X-129 Some Frequently Recommended Works on Rhetorical, Communications, and Discourse Theory

X-139 Some Frequently Recommended Works on Style and Stylistics

X-164 Some Frequently Recommended Works on Composition and the Teaching of Writing

Y-39 Some Frequently Recommended Works on Analytical and Descriptive Bibliography and on Textual Criticism

Y-49 Guide to English Book-Trade Lists

Y-52 Guide to American Book-Trade Lists

Y-59 Some Frequently Recommended Works on the History of Printing and the Book Trade and on the Cultural Significance of the Book

Y-69 Guide to Works on the Private Libraries of English and American Authors

Y-88 Some Frequently Recommended Works on the History of Book and Manuscript Collecting

Y-89 Some Catalogs of Famous Private Collections Relating to English and American Language and Literature

Y-99 Some Frequently Recommended Works on the History of Libraries and Librarianship

Z-19 Some Frequently Recommended Works on the Profession of English

Z-28 Guide to Sources of Information about Associations, Societies, and Organizations

Z-29 Guides to the Publications of Leamed Societies

Z-49 Some Frequently Recommended Works on Research Design and Methodology

Z-54 Some Frequently Recommended Studies in Dating, Attribution, Authenticity, and Composition

Z-59 Some Frequently Recommended Works on Annotation

Z-64 Some Frequently Recommended Studies of Sources and Influences

Z-66 Aids for Locating Contemporary Reviews

Z-67 Some Frequently Recommended Reception Studies

Z-68 Some Frequently Recommended Works on Specific Research Methods, Techniques, or Projects

Z-78 Guide to Computerized Data Bases Useful in Literary Research

Z-79 Some Frequently Recommended Works on Computers and the Humanities

Z-89 Some Additional Guides to Securing Fellowships and Grants

Z-99 Some Frequently Recommended Works on Scholarly Writing

Z-109 Some Frequently Recommended Works on Scholarly Publishing

Z-119 Some Frequently Recommended Works on Academic Employment and Related Topics 
2-139 Some Frequently Recommended Works on Teaching, the Teaching of English, and Research in the Teaching of English

Z-149 Some Frequently Recommended Works on Alternative Careers
Z-159 Some Frequently Recommended Works on the Humanities in Our Time 